\title{
The Relationship Between South Asian Stock Returns and Macroeconomic Variables
}

\author{
M. N. Khan ${ }^{\mathrm{a}}$, N. Tantisantiwong ${ }^{\mathrm{b}, *}$, S. G. M. Fifield ${ }^{\mathrm{c}}$, D. M. Power ${ }^{\mathrm{c}}$ \\ a Institute of Management Sciences, University of Science and Technology Bannu, Pakistan \\ b Southampton Business School, University of Southampton, UK \\ ${ }^{c}$ School of Business, University of Dundee, UK
}

\begin{abstract}
This article investigates whether economic variables have explanatory power for share returns in South Asian stock markets. In particular, using data for four South Asian emerging stock markets over the period 1998 - 2012, the article examines the influence of a selection of local, regional and global economic variables in explaining equity returns; most previous studies that have examined this issue have tended to focus on only local and/or global factors. Important factors are identified by distilling the macroeconomic variables into principal components. Economic activities, real interest rates, real exchange rates and the trade balance represent local factors. Regional factors are represented by inter-regional trade and regional economic activity while global factors are represented by world financial asset returns and world economic activity. The Vector Autoregression results suggest that the South Asian markets examined are not efficient. Both local and regional factors can directly and indirectly explain Bangladeshi, Pakistani and Sri Lankan stock returns while the lagged returns of the Pakistani stock market and world economic activity can explain Indian stock returns.
\end{abstract}

* Corresponding author. E-mail: n.tantisantiwong@soton.ac.uk 


\title{
The Relationship Between South Asian Stock Returns and Macroeconomic Variables
}

\begin{abstract}
This paper investigates whether economic variables have explanatory power for share returns in South Asian stock markets. In particular, using data for four South Asian emerging stock markets over the period 1998 - 2012, the paper examines the influence of a selection of local, regional and global economic variables in explaining equity returns; most previous studies which have examined this issue have tended to focus on only local and/or global factors. Important factors are identified by distilling the macroeconomic variables into principal components. Economic activities, real interest rates, real exchange rates and the trade balance represent local factors. Regional factors are represented by inter-regional trade and regional economic activity while global factors are represented by world financial asset returns and world economic activity. The Vector Autoregression results suggest that the South Asian markets examined are not efficient. Both local and regional factors can directly and indirectly explain Bangladeshi, Pakistani and Sri Lankan stock returns while the lagged returns of the Pakistani stock market and world economic activity can explain Indian stock returns.
\end{abstract}




\section{Introduction}

This study examines whether macroeconomic factors influence the equity returns of South Asian stock markets. To date, a large number of articles have focused on the relationship between macroeconomic variables and stock returns in developed markets (Kim, 2003; Humpe and Macmillan, 2009) as well as in some emerging stock markets of Latin America (Verma and Ozuna, 2005; Abugri, 2008) and Eastern Europe (Hanousek et al., 2009). However, relatively few studies have focused on South Asian stock markets despite the fact that Bangladesh, India, Pakistan and Sri Lanka have experienced an economic transformation over the past 15 years and barriers to international trade have been lowered. For instance, growth in gross domestic product (GDP) for the four countries averaged 7.30 percent over the years 2001 to 2012 while foreign direct investment (FDI) as a percentage of GDP increased by more than 51 percent over the same period (World Bank, 2012). Moreover, net inflows of foreign equity investment for the four countries was recorded at about 135 billion USD during 2001-2012, accounting for nearly 100 percent of foreign equity investment in South Asia and about 20 percent of foreign equity investment in low and middle income countries. Although most of this foreign equity investment was directed towards India ${ }^{1}$, the other stock markets in the region have also been attractive to foreign investors; the Bloomberg Riskless Return Ranking rated the Pakistan’s KSE100 as offering the world's best risk-adjusted returns in 2012 while Sri Lanka's Colombo All-share Index was rated second over 2009-2011 (Bloomberg, 2012). The stock markets of the four countries examined in this paper have all promoted harmonization policies and allowed foreign investors to buy equities in locally listed companies following the establishment of the South Asian Federation of Exchanges (SAFE) in 2000 (Khan, 2013). The current investigation analyses whether this period of unprecedented economic development in the four countries

\footnotetext{
${ }^{1}$ India also attracted the bulk of FDI inflows. For example, the World Bank (2013a) reported that India accounted for approximately 85.0 percent of South Asia's FDI inflows in 2010.
} 
can explain changes in each nation's equity returns or whether regional and global influences have a part to play in understanding why share price movements have occurred.

Finance theory as well as prior empirical evidence suggests that shocks to macroeconomic variables should affect stock market returns; indeed, several multifactor asset pricing models, such as the Arbitrage Pricing Theory (APT), have been developed on the basis of this assumption ${ }^{2}$. Previous studies have assumed either perfect integration among markets whereby share returns have a linear relation with a number of global factors (e.g. Ferson and Harvey, 1994; Dumas and Solnik, 1995; Harvey, 1995) or complete segmentation with share returns determined by local economic variables (e.g. Chen et al., 1986; Ahmed and Imam, 2007; Mahmood and Dinniah, 2009). However, empirical investigations have generally documented that emerging markets are only partially integrated with the global market (e.g. Bekaert and Harvey, 1995; Chen et al, 2002; Click and Plummer, 2005). Therefore, neither the assumption of perfect integration nor complete segmentation is realistic for emerging markets (Bilson et al., 2001). In addition, the simple dichotomy of local versus global economic variables ignores the important role that regional influences may play in explaining equity returns; for example, as growing economic and financial ties between Bangladesh, India, Pakistan and Sri Lanka have increased and conflicts in the area have been resolved, linkages among share returns may have risen and the regional influence grown (Khan, 2013). Hence, the current paper studies whether local, regional and global economic variables determine stock returns in the South Asian region.

In the current paper, a total of 17 macroeconomic variables are investigated. While most of the previous studies which focus on stock returns in South Asia have ignored the effect of regional and world macroeconomic variables, this paper considers six local, six regional and five global economic variables. The local economic variables include the

\footnotetext{
${ }^{2}$ However, the APT, which was proposed by Ross (1976), fails to identify both the number and the nature of the relevant factors which are important in explaining returns (Dhrymes et al., 1985). The selection of relevant factors is therefore subjective and an unavoidable problem associated with this area of research (Fama, 1991).
} 
industrial production index, the consumer price index, the trade balance, the nominal exchange rate, money supply and the interest rate. The six regional variables are regional GDP, the regional inflation rate, the ratio of regional money supply to regional GDP, the ratio of regional trade balance to regional GDP, the ratio of inter-regional trade to regional GDP and the ratio of the total value of shares traded in South Asian stock markets to regional GDP. The five global variables include the US Treasury-bill rate, the world stock market return, world GDP, the world inflation rate, and the world oil price. Economic motivations were used to select these variables for inclusion in the study. Principal Components Analysis (PCA) was first applied in order to identify important economic factors ${ }^{3}$. Then, the possible relationship between stock returns and economic factors was investigated using both multiple regression as well as the vector autoregression (VAR) method. The result indicates that local and regional economic factors have a greater influence on stock returns in Bangladesh, Pakistan and Sri Lanka while global economic activity has a greater influence on the stock returns of India.

The remainder of the paper is organized as follows. Section 2 briefly discusses the existing literature about the relationship between macroeconomic variables and stock returns. Section 3 introduces the dataset and presents some descriptive statistics for the data. The results from the PCA are described in Section 4. In Section 5, the role of local, regional and global factors in explaining South Asian emerging stock market returns is explored. Finally, Section 6 offers a number of concluding observations.

\section{Literature Review}

Numerous studies provide results in support of a contemporaneous relationship between changes in share prices and variations in macroeconomic variables (Bilson et al.

\footnotetext{
${ }^{3}$ PCA also helps to reduce the loss of degrees of freedom and overcomes any problems with multicollinearity due to the correlations between macroeconomic variables (Jolliffe, 1972).
} 
2001; Fifield et al. 2002; Fifield and Power, 2006) and a relationship between current changes in share prices and past changes in macroeconomic variables (Fama, 1981; Chen et al., 1986; Rapach et al., 2005). Various econometric techniques such as cointegration (Nasseh and Straus, 2000; Acikalin et al., 2008), VAR (Abugri, 2008) and Granger causality analysis (Wongbangpo and Sharma, 2002) have been applied. However, different sets of macroeconomic variables have been found to be significantly related to equity values in different stock markets. For example, Poon and Taylor (1991) found that the macroeconomic variables which influenced UK returns were different from those which determined US equity price changes. Humpe and Macmillan (2009) found a long-run relationship between share prices and industrial production, the inflation rate and long-term interest rates in the US market, but a long-run relationship between share prices and industrial production and money supply in the Japanese market. More recently, Birz and Lott (2011) examined news about GDP growth, unemployment, retail sales, and durable goods and found that only news about GDP growth and unemployment significantly affected stock returns in the US.

Similarly, there is mixed evidence regarding the nature of the relationship between particular economic factors and share returns. For example, some studies have documented a negative relationship between share price changes and inflation (Fama, 1981; Chen et al., 1986); while others have reported a positive association between share prices and inflation in hyper-inflationary environments in countries such as Argentina, Chile, Mexico and Venezuela (Choudhry, 2001). Wongbangpo and Sharma (2002) suggested that the reason for a positive association between the two variables in hyper-inflationary economies is that share prices act as a hedge against inflation. However, Sing and Low (2000) and Zhou et al. (2005) called this reasoning into question by suggesting that equity investments are poor hedges against inflation. The evidence from existing studies on the relationship of the exchange rate and money supply with share prices is also mixed. For example, Wongbangpo and Sharma 
(2002) argued that depreciation in the local currencies against the US dollar in Indonesia, Malaysia and the Philippines enhanced their competitiveness in the world exporting market and, hence, had a positive impact on stock market performance. By contrast, the relationship between exchange rates and stock prices in Singapore and Thailand was negative and was explained by the asset market view of the exchange rate that contends that the demand for, and value of, local currencies is driven by foreign investors' willingness to hold local assets (Ajayi and Mougoue, 1996). In a similar vein, Wongbangpo and Sharma (2002) argued that a positive or a negative relationship may exist between share price changes and variations in the money supply. The evidence on the relationship between interest rates and share returns is also mixed; some studies have reported a negative relationship (Nelson, 1976; Fama and Schwert, 1977; Fama, 1981) while others have documented a positive relationship (Firth, 1979; Gultekin, 1983; Flannery and James, 1984). A positive association between output and share prices has been documented for both developed and developing countries (Wongbangpo and Sharma, 2002; Kim, 2003; Fifield and Power, 2006; Humpe and Macmillan, 2009).

Global economic variables have also been found to be important in explaining returns in emerging stock markets (ESMs). For example, the world equity market return, the return on a foreign exchange index, oil prices, world industrial production and the world inflation rate have been found to characterise returns in emerging stock markets (Harvey, 1995; Fifield et al., 2002). Some studies have also examined the relative importance of global and local economic variables. For example, Fifield et al. (2002) employed PCA to distil several local and global economic variables into key principal components (PCs) before analysing the association of PCs with stock returns for 13 ESMs. Four local factors (GDP, inflation, the money supply and interest rates) and two global factors (world industrial production and world inflation) were extracted. The results indicated that stock markets in Greece, Korea, 
Mexico, Portugal, Singapore and Thailand were more integrated with the global market, while stock markets in India and Turkey were more segmented at the time of their study. These results confirmed the findings of Nasseh and Straus (2000) who discovered a significant relationship between share prices and both local as well as foreign macroeconomic variables. Extending Fifield et al. (2002), Fifield and Power (2006) included fundamental factors in a study of share returns in 11 ESMs over the 10 year period from 1991 to 2000. Six of the countries selected were from East and South East Asia while five were from other continents. The results indicated that local and global economic factors such as GDP, inflation, the money supply, interest rates, world GDP and the world market return had an impact on the stock markets of both Asian and non-Asian countries. The results further suggested that local factors were important in explaining equity returns in both regions whereas global (fundamental) factors were more important in Asian (non-Asian) stock markets. Overall, it appeared that Asian stock markets were influenced more by the economic performance of developed countries.

Studies which have focused on South Asian countries are fairly dated and have generally examined the countries individually and with a relatively small number of variables. For example, Gunasekarage et al. (2004), Ahmed and Imam (2007), Ahmed (2008) and Sohail and Hussain (2009) studied the relationship between economic variables and stock market performance in Sri Lanka, Bangladesh, India and Pakistan, respectively. In addition, these studies examined the relationship between domestic economic variables and share returns and ignored the influence of international factors on the equity price changes in these markets (hence assuming complete segmentation of these markets from the world financial system). The evidence from these studies about macroeconomic variables and share returns is mixed. For example, Gunasekarage et al. (2004) argued that most of the variation in the Sri Lankan stock market index was explained by its own historical information and that 
economic variables had very little influence on share prices. Ahmed (2008) found that the performance of the domestic economy was more important in influencing the stock market than international trade and FDI. Sohail and Hussain (2009) reported a negative relationship between inflation and share prices in the Lahore Stock Exchange in Pakistan, whereas industrial production, exchange rates and the money supply all had a positive relationship with share prices. While most of the previous studies focusing on South Asia have investigated the relationship between stock markets and domestic macroeconomic variables only, this paper considers a large number of domestic and international economic variables.

\section{Data and Descriptive Statistics}

The South Asian stock markets investigated in this paper include Bangladesh, India, Pakistan and Sri Lanka. Monthly S\&P indexes ${ }^{4}$ for these stock markets were obtained from Datastream for the 15-year period January 1998 to December 2012. The time span analysed covers a period of stock market development and liberalisation in these four stock markets as a result of the formation of SAFE in 2000. As the stock indexes are non-stationary, they were transformed into stock returns so that the Ordinary Least Squares (OLS) estimation could be employed. The index returns were calculated as the first differences of the natural logarithm of stock index values.

The macroeconomic variables were chosen for inclusion in the analysis based on economic considerations ${ }^{5}$. In particular, six local variables were selected as follows: the inflation rate which is the growth in the consumer price index (CPI), output growth as proxies for by growth in the industrial production index (IPI), the change in the three-month

\footnotetext{
${ }^{4}$ To calculate these indices, S\&P selects stocks based on market capitalisation and liquidity, with the objective of capturing 80 percent of the total stock market capitalisation in order to represent the trading reality of each market.

${ }^{5}$ According to Alexander (2001) the variables should be made stationary before the PCA is applied, otherwise the first PC will be dominated by the input variable with the greatest volatility. Therefore, the growth rates of economic variables were used for the PCA.
} 
Treasury-bill rate (TBR), the growth in the money supply (MS), the exchange rate returns (FX), and the growth in the trade balance (TB). The first three variables measure the internal economic stability of a country while the last two variables measure the external economic performance. The growth in the money supply indicates the monetary policy stance of the country. These local variables were selected for examination based on the argument that the intrinsic value of an equity depends on the present value of dividends which are distributed out of corporate earnings; these earnings are influenced by real economic activities. Changes in these variables will affect the firm's cash flows and will also influence the risk-adjusted discount rate. Hence, there should be a relationship between economic variables and share prices (LeRoy and Porter, 1981; Shiller, 1981; Flannery and Protopapadakis, 2002). Specifically, inflation is included in the analysis as it may have a positive or negative relationship with share returns. That is, a rise in inflation may lower share prices because of greater volatility that may occur in firm output prices. By contrast, nominal asset returns may be positively related to inflation, thus providing support for the Fisher hypothesis. Output growth is included as, with a relatively fixed supply of shares, increased output may lead to a higher demand for shares and a concomitant rise in share prices (Shiller, 1984). The TBR variable may have a negative or positive impact on share prices. That is, higher rates should result in an increased demand for interest-bearing securities and a reduction in the demand for equities because of the larger opportunity costs involved; therefore, share prices should decline. In addition, a rise in interest rates may result in lower levels of capital expenditure as a result of lower net present value estimates which might, in turn, reduce earnings, cut dividends and lead to lower share prices. However, the Fisher hypothesis suggests that nominal interest rates are positively correlated with inflation, and Flannery and James (1984) reported a positive relationship between interest rates and stock returns. Moreover, the TBR 
is sometimes used as the policy rate to signal the economic situation; a higher TBR may reflect better economic conditions which may be followed by higher share prices.

In terms of the two measures of external economic performance, the FX variable is employed to provide a measure of a change in a country's currency value. Currency depreciation may have a positive or negative impact on the domestic stock market in exportoriented countries. For example, when the domestic currency depreciates relative to the US dollar, exports from the domestic market may become cheaper in the US market. Increased exports may result in higher corporate profitability for firms which sell their products to US customers and share prices may rise as a result. By contrast, currency depreciation may have a negative impact on share prices if many companies use imported products in the production process. Finally, the trade balance is included as a measure of a country's change in international trade performance and the flow of domestic currency. Economic theory suggests that a trade balance surplus should result in higher corporate profits and, hence, share prices should increase; the opposite may be true in the case of a deficit (Mun, 2012).

A number of regional and global variables are also included in the analysis given the increasing integration of South Asian countries into the global economy that has occurred over the last 15 to 20 years (World Bank, 2010) and the establishment of SAFE. This increased integration is reflected in financial statistics which show that, although South Asia has tended to lag behind other developing countries, FDI and foreign portfolio investment (FPI) increased significantly over the 1999 - 2012 period (World Bank, 2013b). For example, total FDI and FPI flows into South Asia increased from $\$ 4.2$ billion in 1999 to $\$ 41.2$ billion in 2012 (Srinivasan, 2002; World Bank, 2013b). Given the increasing reliance of South Asia on foreign trade and investment, it is reasonable to expect that share returns in this region will be influenced to some extent by regional and global factors. That is, news about macroeconomic variables may transmit to cross-border asset returns through international 
trade and financial market integration (Mun, 2012). Indeed, such transmission is apparent from the global financial crisis that started in September in 2008. The South Asian countries were significantly affected by this crisis; investor confidence in domestic financial markets was the first channel by which the crisis was transmitted. The real sector experienced a negative impact very quickly afterwards when investment growth collapsed and output plummeted (World Bank, 2010).

In order to analyse the impact of international factors on South Asian share returns, six regional and five global variables were included in the study ${ }^{6}$. Regional economic variables include regional GDP growth (RGDP), the regional inflation rate (RCPI), regional money supply as a percentage of regional GDP (RMS), trade with other regions as a percentage of regional GDP (RINT), regional trade balance as a percentage of regional GDP (RTB), and the total value of shares traded as a percentage of regional GDP (RMV). While RGDP measures regional economic activity, RCPI measures price instability in the region. Given the fact that a crisis occurring in one country may lead to a crisis in neighbouring countries, the economic weakness or instability of the region can affect a local economy as well as the stock market. The size of the RMS and RMV indicates the importance of money and equity markets to the regional economy as well as the depth of financial markets in the region. The greater development of regional financial markets can attract more foreign investment to the local stock market especially in the region with international financial cooperation like South Asia. As these countries are major exporters, RINT and RTB are included in this analysis. RINT measures the openness of the region while RTB reflects how much the regional economy relies on external demand. If RTB is in deficit, the region has higher imports than exports and indicates that the economy of the region is weaker and may

\footnotetext{
${ }^{6}$ In this paper, the effects of the global financial crisis and financial liberalisation on South Asian stock markets were investigated by including both regional and global economic variables in the analysis. Alternatively, the effects were also investigated by including two dummy variables representing the global financial crisis and the liberalisation; however, their coefficients were insignificant. The results from this analysis are available from the authors upon request.
} 
lead to lower foreign equity investment in regional stock markets and, therefore, lower regional share prices.

The five global variables include world inflation (WCPI) which measures global price changes, world GDP growth (WGDP) as a measure of global economic activity, the world market return (WRET) as measured by the MSCI world price index, the US three-month Treasury-bill rate (USTBR) as a proxy for the global risk-free rate, and finally, world oil prices (OIL). WCPI was included due to the impact that inflation has on currencies and, hence, exports and imports, while WGDP was selected as world economic growth may impact on exports and hence, corporate profitability and share prices. To investigate possible stock market synchronisation between South Asia and other markets, WRET was included in the analysis. The increased international capital flows that South Asia has attracted in recent years provides a propagation channel for capital flow reversals, such as those which occurred during the 2008 global financial crisis. That is, losses in one market may induce investors to rebalance their portfolios and sell investments in other markets (Walti, 2005). Indeed, herding behaviour causes global investors to make similar buy and sell decisions. The USTBR variable was included as it may influence the actions of both foreign and domestic investors. That is, an increase in US interest rates may reduce the demand for equities amongst investors; the demand for US interest-bearing securities may increase and portfolio rebalancing may mean that investment in the other markets may decline. Finally, OIL was added because of the worldwide importance of this commodity as a main input in production. An increase in oil prices would result in higher costs and, hence, lower equity values (Harvey, 1995). Out of the sample markets considered, India is ranked as the fourth of the world's major oil importers, Pakistan as the 29th, Sri Lanka as the 68th and Bangladesh as the 76th. Monthly data of each macroeconomic variable were obtained from Datastream and the International Financial Statistics yearbooks of the International Monetary Fund (IMF). 
Table 1 reports the mean value (Mean) and standard deviation (SD) of the returns and the growth rate of selected economic variables for the four South Asian countries, the South Asian region and the world. A number of points emerge from an analysis of the table. First, the mean return varied slightly among the four markets during 1998-2012. Sri Lanka performed the best with a mean return of 1.3 percent per month. This was followed by Pakistan and India with mean return values of 1.2 percent and 1.1 percent, respectively. The lowest average return for the period was that of Bangladesh with a mean value of 1.0 percent. Second, returns of the four markets were more volatile than the world market. The Indian market was the least risky market with a standard deviation value of 7.9 percent and Pakistan was the most risky market with a standard deviation value above 11.0 percent

[Insert Table 1 about here]

Third, the table indicates that the growth in money supply increased almost uniformly in the four countries over the sample period. Pakistan showed the lowest inflation rate of 0.1 percent per month; by contrast, the rest of the three countries showed a uniform monthly inflation rate of 0.5 percent over the sample period. Although the mean inflation rate was low in Pakistan, the high standard deviation value reflects high levels of price instability in the country. Output growth was highest in India (0.6 percent per month) closely followed by Bangladesh (0.5 percent per month). The economies of Pakistan and Sri Lanka grew at the slightly slower rates of 0.3 and 0.4 percent per month with standard deviation values of 10.1 and 7.2 percent per month, respectively. The volatile nature of IPI for Pakistan and Sri Lanka may have been due to the political unrest in the two countries; this instability resulted in the temporary disruption of production from time to time (Daily The Nation, 2010). 
Fourth, the currencies for all four markets depreciated relative to the US dollar over the sample period, leading to an improvement in the trade balance of these countries. This currency depreciation possibly helped the exports of these countries to grow. Indeed, an examination of trade data showed that the sales of goods and services abroad increased by 1.3 and 1.4 percent per month in Bangladesh and India, and by 1.1 percent and 0.9 percent per month in Pakistan and Sri Lanka, respectively. This growth in exports was matched by a sizeable rise in imports, possibly as manufacturers imported raw materials for production purposes. However, the growth in RTB decreased over the sample period, indicating that the regional economy became less dependent on demand from other regions. Finally, an inspection of Table 1 reveals that the Treasury-bill rates in South Asia rose as the US Treasury-bill rate declined. The Treasury-bill rate for Bangladesh and Pakistan increased by 0.21 and 0.24 percent per month, respectively, while it increased by just 0.09 and 0.04 percent per month for India and Sri Lanka, respectively.

\section{Identification of Economic Factors}

To investigate the relationship between stock returns and six local, six regional and five global macroeconomic variables in South Asian emerging markets, the paper employs PCA to extract main factors from the pool of data under examination. PCA is a method which significantly reduces the number of correlated variables from $p$ to a small number of uncorrelated $k$ PCs. PCA therefore allows a large number of macroeconomic variables that may affect stock returns to be considered simultaneously. It is effective in addressing the problem of multicollinearity as the $k$ PCs are orthogonal to each other. Since the PCs are uncorrelated, each regression coefficient can be estimated independently of the other components in a model. This makes it easy to choose the optimal set of predictors for the empirical analysis being conducted (Dunteman, 1994). In the current paper, the economic 
variables under consideration are highly correlated and thus PCA is deemed an appropriate method for dealing with this issue. The loadings are extracted from the PCA and these are then used to construct PCs which are included as independent variables in a VAR model. According to Dunteman (1994), the variable with the highest loading or weight for a PC should be used as a representative of that PC. However, following Fifield et al. (2002), loadings for all variables are considered in the construction of the PCs. This approach allows each variable - even those with small weights - to contribute to the construction of the PC.

According to the Kaiser criterion, PCs with latent roots or eigenvalues greater than one should be retained (Kaiser, 1960). This recommendation was adopted in the current paper. Table 2 details the eigenvalues, the proportions and the cumulative proportions of variance explained by the PCs. An analysis of this table shows that the adoption of the Kaiser criterion resulted in the retention of three PCs for the local variables in all four markets under investigation, two PCs for the regional variables and two PCs for the global variables.

[Insert Table 2 about here]

A visual inspection of Table 2 indicates that, in all four emerging markets, the first three PCs account for 57.7, 65.2, 71.5 and 57.7 percent of the variation in the macroeconomic variables for Bangladesh, India, Pakistan and Sri Lanka, respectively. Table 3 shows that the three local PCs are different across countries.

In particular, MS has a high loading in the first local PC (LPC1) for all countries. TB is the second common variable in LPC1 for Pakistan and Sri Lanka with a negative loading for Pakistan and a positive loading for Sri Lanka. While TBR has a high loading in Bangladesh and Sri Lanka, IPI has a high loading for India. The high loadings for these variables is understandable; these countries have generally been characterised as export- 
oriented economies during the period under consideration (Fifield and Power, 2006). Given that LPC1 is made up mainly of MS and TBR in Bangladesh and Sri Lanka, LPC1 is labelled as the 'real interest rate' for Bangladesh and Sri Lanka7. By contrast, LPC1 is labelled as 'economic activity' and 'trade deficits' in India and Pakistan, respectively.

The second local PC (LPC2) is constituted mainly of FX and TB for all countries except Pakistan. IPI is important for Bangladesh and Pakistan while CPI is important for Pakistan and Sri Lanka. Thus, LPC2 may be termed as 'economic activity' in Bangladesh and Pakistan and the 'real exchange rate' in India and Sri Lanka.

The third local PC (LPC3) has CPI as a common variable in Bangladesh, India and Pakistan, FX in Bangladesh and Pakistan, and TBR in India and Pakistan. LPC3 is therefore labelled the 'real exchange rate' in Bangladesh and Pakistan and the 'real interest rate' in India. In Sri Lanka, LPC3 is labelled as 'economic activity' due to the high loading of IPI.

Even though each LPC is named differently for the four countries, their LPCs include the real interest rate, the real exchange rate and economic activity. It is only Pakistan that has the trade deficit as a dominant component rather than the real interest rate. These economic factors are key indicators of the finance and production sectors of an economy.

[Insert Table 3 about here]

The analysis of regional variables indicates that the first PC accounts for 55.3 percent of the variation and the second PC explains 20.7 percent of the variation in the six regional variables. The weighting of the first regional PC (RPC1) indicates that RTB and RINT are relatively high with a negative loading for TB and a positive loading for RINT. Thus, RPC1

\footnotetext{
7 The interest rates and exchange rates used in the PCA are nominal rates. However, as the loadings for the interest rates and exchange rates obtained from the PCA have the opposite sign to the inflation rate or growth in money supply, the local PCs are termed as 'the real interest rate' and 'the real exchange rate'.
} 
is termed 'inter-regional trade deficit'. For the second regional PC (RPC2), RGDP and RMV are the dominant components, so it is termed 'regional economic activity'.

An analysis of the results for the global economic variables indicates that the first PC accounts for 36.6 percent of the variation, whereas the second PC contributes 25.0 percent of the variation in the five global variables under examination. According to Table 3 , the weightings for WCPI, OIL and WRET are relatively high in the first global PC (GPC1). WGDP and the USTBR have relatively higher loadings in the second global PC (GPC2). Thus, GPC1 is more related to the real return on the world's financial assets while GPC2 is deemed to measure world economic activity.

Overall, the results confirm that this region is export-oriented and that regional and global economic factors should be considered when the relationship between stock returns and macroeconomic variables is investigated. The dominant PCs extracted for further analysis include key economic factors for the four sample countries, the South Asian region and the world.

\section{The Role of Macroeconomic Factors in Explaining Stock Returns}

In this section, the dominant PCs from the PCA which are highlighted in Table 3 are used as economic factors in regressions of the index returns of the four South Asian emerging markets. Specifically, two types of regressions are estimated for each market; one is a multiple regression and another is a first order Vector Autoregression (VAR(1)).

Two multiple regressions with different sets of exogenous variables are estimated for each market: one with local PCs and another with additional regional and global PCs. These two regressions are shown in Equations (1) and (2):

$R_{i t}=a_{i}+b_{0 i} R_{i t-1}+b_{1 i} L P C 1_{i t-1}+b_{2 i} L P C 2_{i t-1}+b_{3 i} L P C 3_{i t-1}+e_{i t}$ 


$$
\begin{aligned}
R_{i t}= & a_{i}+b_{0 i} R_{i t-1}+b_{1 i} L P C 1_{i t-1}+b_{2 i} L P C 2_{i t-1}+b_{3 i} L P C 3_{i t-1} \\
& +c_{1 i} R P C 1_{i t-1}+c_{2 i} R P C 2_{i t-1}+d_{1 i} G P C 1_{i t-1}+d_{2 i} G P C 2_{i t-1}+w_{i t}
\end{aligned}
$$

where $R_{i t}$ represents the $i^{\text {th }}$ stock markets' returns, and $e_{t}$ and $w_{t}$ are random error terms.

The estimates of Equation (1) permit an analysis of the impact of local factors on the index returns of the four South Asian emerging markets. Equation (2) in conjunction with Equation (1) can be used to identify the incremental change in the explanatory power from adding the regional and global PCs to the local PC information set. An analysis of the model also facilitates a test of the significance of each local, regional and global PC in explaining the returns earned in all four South Asian emerging markets.

Table 4 reports the OLS results from estimating Equations (1) and (2). It reports the coefficient values of each PC and the $\mathrm{R}^{2}$ and adjusted $\mathrm{R}^{2}$ values for both regressions. The standard errors are estimated using the Newey-West procedure which corrects for heteroscedasticity and autocorrelation (Gujarati, 2004). A visual inspection of Table 4 reveals a number of findings. First, the ability of economic variables to explain returns in the four South Asian emerging markets returns is limited. For example, the explanatory power of the local factors ranges from a low of 0.0 percent in India to a high of 5.0 percent in Sri Lanka. In Bangladesh, India and Sri Lanka, the total explained variation increases on the addition of the regional and global factors to the regression model. However, a sizeable proportion is still unexplained for the returns in these markets. For example, in the case of India, 5.0 percent of the variation of stock price changes can be explained by the model which includes both regional and global PCs, but 95.0 percent of the total variance of returns remains unexplained. These results are very similar to the findings reported for other emerging markets $^{8}$. Second, the Indian stock market return cannot be predicted using its own previous value and economic factors. By contrast, stock market returns can be explained partly by

\footnotetext{
${ }^{8}$ Hondroyiannis and Papapetrou (2001) argued that although macroeconomic activities affected the performance of Greek equities, a substantial proportion of the variation in returns was not explained by economic variables.
} 
local and regional economic factors in Bangladesh and Sri Lanka, but only by local economic factors in Pakistan. Finally, in the case of Bangladesh and Sri Lanka, the addition of the regional variables increases the $\mathrm{R}^{2}$ by about 132.0 percent and 78.0 percent, respectively. Therefore, the results provide support for the view that both domestic and international forces affect returns in these markets.

[Insert Table 4 about here]

Next, a VAR(1) model is estimated to allow for the investigation of bi-directional relationships between the returns on stock market $i$ and local economic factors. In addition, the model is designed to examine whether the return on stock market $i$ and local economic factors also relates to the returns on the other three stock markets as well as regional and global economic factors. The market returns in the other three stock markets and the regional and global economic factors are included in the VAR(1) model as exogenous variables. The specification of the VAR(1) model is shown in Equation (3):

$Y_{i t}=\mathrm{A}_{i}+B_{i} Y_{i t-1}+\Gamma_{i} Z_{i t-1}+\Theta_{i} R P C_{t-1}+\Delta_{i} G P C_{t-1}+U_{i t}$

where

$\begin{aligned} A_{i} & =\left[\begin{array}{l}a_{0 i} \\ a_{1 i} \\ a_{2 i} \\ a_{3 i}\end{array}\right] B_{i}=\left[\begin{array}{llll}b_{0 i} & b_{01 i} & b_{02 i} & b_{03 i} \\ b_{10 i} & b_{1 i} & b_{12 i} & b_{13 i} \\ b_{20 i} & b_{21 i} & b_{2 i} & b_{23 i} \\ b_{30 i} & b_{31 i} & b_{32 i} & b_{3 i}\end{array}\right] ; \\ \Gamma & =\left[\begin{array}{lll}\gamma_{01 i} & \gamma_{02 i} & \gamma_{03 i} \\ \gamma_{11 i} & \gamma_{12 i} & \gamma_{13 i} \\ \gamma_{21 i} & \gamma_{22 i} & \gamma_{23 i} \\ \gamma_{31 i} & \gamma_{32 i} & \gamma_{33 i}\end{array}\right] ; \Theta_{i}=\left[\begin{array}{ll}\theta_{01 i} & \theta_{02 i} \\ \theta_{11 i} & \theta_{12 i} \\ \theta_{21 i} & \theta_{22 i} \\ \theta_{31 i} & \theta_{32 i}\end{array}\right] ; \Delta_{i}=\left[\begin{array}{ll}\delta_{01 i} & \delta_{02 i} \\ \delta_{11 i} & \delta_{12 i} \\ \delta_{21 i} & \delta_{22 i} \\ \delta_{31 i} & \delta_{32 i}\end{array}\right]\end{aligned}$ 
$Y_{\text {it }}$ is the column vector of endogenous variables including the $i^{\text {th }}$ stock markets' returns and three local PCs. $Z_{i t}$ is the column vector of the returns on the other three stock markets. RPC and $\mathrm{GPC}_{\mathrm{t}}$ are column vectors of two regional and two global PCs, respectively. $\mathrm{U}_{\mathrm{it}}$ is the column vector of random error terms.

[Insert Table 5 about here]

Unlike the results of Equations (1) and (2) which ignore the bi-directional relationship between stock market returns and local economic factors, the VAR model results indicate that stock returns in all four South Asian markets are predictable, implying that these markets are inefficient. A visual inspection of Table 5 reveals that the only market that is affected by another market in this region is India; it is affected by lagged Pakistani stock returns.

According to Table 5, local economic factors can affect Bangladeshi, Sri Lankan and Pakistani stock market returns, but not Indian stock market returns. This result contradicts Fifield et al. (2002) who found that domestic economic factors were important in explaining stock returns in India. The significance of the local economic factors varies across the three markets. That is, the important local economic factor for Bangladeshi stock returns is the real interest rate (LPC1) while the trade balance and the real exchange rate (LPC1 and LPC3) are influential in the Pakistani equity market and the real interest rate and the real exchange rate (LPC1 and LPC2) are influential in the Sri Lankan equity market. The VAR models reveal that a decline in the real interest rate can lower stock returns ${ }^{9}$ as the lower cost of borrowing leads to higher output which causes a decline in prices and inflation. On the other hand, an appreciation of currency can lead to higher stock returns. A lower trade deficit indicates an improvement in the economic situation of a country which may result in greater foreign

\footnotetext{
${ }^{9}$ Mundell (1963) found that the real financial asset return was negatively correlated with real economic activity.
} 
investment and higher stock returns. Local economic activities (LPC2 for Bangladesh and Pakistan, LPC1 for India and LPC3 for Sri Lanka) do not have a significant impact on stock returns in these emerging markets.

A different picture emerges when the regional PCs are examined. In particular, the results indicate that regional economic performance has a direct effect on the Bangladeshi stock market and indirect effects on the Pakistani and Sri Lankan stock markets, but no impact on the Indian stock market. By contrast, global economic performance affects only the Indian market. Regarding the direct impact of external factors, Table 5 shows that increased regional (global) economic activity may lead to higher stock returns in Bangladesh (India). An explanation for these findings may be that the Indian economy and stock market are relatively more integrated into the global economy as compared to the other three countries. This finding is consistent with the fact that India is a major exporting country; in 2012, it was ranked as the 24th greatest exporter in the world while Bangladesh, Pakistan and Sri Lanka were ranked 67th, 69th and 92nd, respectively (World Bank, 2012). Moreover, India was ranked by the World Bank as the 14th largest recipient of FDI globally while Pakistan, Bangladesh and Sri Lanka were ranked in the 82nd, 85th and 99th place, respectively. These findings are similar to the results of Fifield et al. (2002) who discovered that global factors were important in explaining stock returns in emerging markets which are highly integrated with the world market.

According to Table 5, there are significant relationships between the local and regional economic factors, but no relationships between the local and global factors. More specifically, greater regional economic activities can lead to a higher real interest rate (in Bangladesh and Sri Lanka), currency depreciation (in all countries with the exception of India) and a lower trade deficit (in Pakistan). According to international economic theory, the greater the amount of capital inflows, the larger the trade deficit. Therefore, inter-regional 
trade deficits may indicate net capital inflows. As shown in Table 5, capital inflows can lead to a lower real interest rate (in Bangladesh and Sri Lanka), currency appreciation (in Bangladesh and Sri Lanka), and a higher level of economic activity (in Bangladesh). The results also show that higher regional trade deficits tend to be followed by a higher trade deficit (in Pakistan) and lower economic activity (in India and Pakistan). Thus, even though there is no direct relationship between Pakistani and Sri Lankan stock returns and regional economic factors, stock returns in these two countries may be indirectly affected by regional economic performance.

Finally, the explanatory power of the VAR model is higher than that of Equation (2) only in the case of India; the explanatory power of the two models are not very different in all other cases. Given that the VAR models allow the indirect effects of regional factors on stock returns to be detected, the VAR model is more comprehensive.

Overall, the results in this paper indicate that the stock markets in the South Asian region are not efficient. The findings indicate the presence of a relationship between stock market returns and macroeconomic variables. In particular, the regression results show that stock market returns in South Asia relate to not only the country's economic factors, but also regional and global economic factors. The relatively greater importance of local components for these emerging markets, with the exception of India, is not wholly surprising given that these countries' economies are less integrated into the global financial system than the other emerging countries of the world. These findings support Lamba (2005) who argued that, with the exception of the Indian market which was influenced by the developed markets of the US, the UK and Japan, the Pakistani and Sri Lankan markets were relatively isolated from the developed markets of the world. 


\section{Conclusion}

This paper has analysed the effect of local, regional and global macroeconomic variables on stock returns in Bangladesh, India, Pakistan and Sri Lanka. The PCA method and regression analyses were employed to identify the theoretically important economic factors which may affect stock returns in these markets.

The paper investigates six local, six regional and five global economic variables. The results from the PCA indicated that economic activity, real interest rates and real exchange rates characterised the local factors with trade balance playing an important role for Pakistan. In addition, regional factors were represented by trade with other regions and regional economic activity while global factors were represented by world financial assets and world economic activity. The regressions indicated that information about real interest rates, real exchange rates and trade explain South Asian stock market returns, but economic activity does not. In addition, regional economic activity directly explains stock returns of Bangladesh and indirectly explains stock returns of Pakistan and Sri Lanka while interregional trade explains these stock returns only indirectly. On the other hand, local and regional economic factors cannot explain stock returns in India. Furthermore, previous stock returns in other South Asian countries, and world economic activity can explain stock returns in India, but not in the other three countries.

In sum, with the exception of India, these South Asian stock markets are weakly integrated with the global financial system. Hence, foreign investors may be able to attain diversification benefits by including equities from this region in their global investment portfolio. The results suggest that investors in the Bangladeshi, Pakistani and Sri Lankan (Indian) stock markets should incorporate local and regional economic news (Pakistani stock returns and global economic news) when making portfolio investment decisions. 


\section{References}

Abugri, B.A. (2008) Empirical relationship between macroeconomic volatility and stock returns: Evidence from Latin American markets, International Review of Financial Analysis, 17, 396-410.

Acikalin, S., Aktas, R. and Unal, S. (2008) Relationships between stock markets and macroeconomic variables: an empirical analysis of the Istanbul Stock Exchange, Investment Management and Financial Innovations, 5, 8-16.

Ahmed, M.N. and Imam, M.O. (2007) Macroeconomic Factors and Bangladesh Stock Market: Impact Analysis through Cointegration Approach, International Review of Business Research Papers, 3, 21-35.

Ahmed, S. (2008) Aggregate Economic Variables and Stock Markets in India, International Research Journal of Finance and Economics, 14, 141-164.

Ajayi, R.A. and Mougoue, M. (1996) On the dynamic relation between stock prices and exchange rates, Journal of Financial Research, 19, 193-207.

Alexander, C. (2001) Market Models: A Guide to Financial Data Analysis, London: John Wiley \& Sons.

Bekaert, G. and Harvey, C.R. (1995) Time-varying World Market Integration, The Journal of Finance, 50, 403-444.

Bilson, C.M., Brailsford, T.J. and Hooper, V.J. (2001) Selecting macroeconomic variables as explanatory factors of emerging stock market returns, Pacific-Basin Finance Journal, 9, 401426.

Birz, G. and Lott Jr, J.R. (2011) The effect of macroeconomic news on stock returns: New evidence from newspaper coverage, Journal of Banking and Finance, 35, 2791-2800.

Bloomberg (2012) Pakistan Stocks Best as Violence Ignored: Riskless Return, Nov: 21.

Chen, G.M., Firth, M. and Rui, O.M. (2002) Stock market linkages: Evidence from Latin America, Journal of Banking and Finance, 26, 1113-1141.

Chen, N., Roll, R. and Ross, S.A. (1986) Economic forces and the stock market, Journal of Business, 59, 3, 383-403.

Choudhry, T. (2001) Inflation and rates of return on stocks: evidence from high inflation countries, Journal of International Financial Markets, Institutions and Money, 11, 75-96.

Click, R.W. and Plummer, M.G. (2005) Stock market integration in ASEAN after the Asian financial crises, Journal of Asian Economics, 16, 5-28.

Daily the Nation, July (2010) Power Failure Halts Business. 
Degiannakis, S., Filis, G. and Floros, C. (2013) Oil and stock returns: Evidence from European industrial sector indices in a time-varying environment, Journal of International Financial Markets, Institutions and Money, 26, 175-191.

Dhrymes, P.J.I., Gültekin, F.M.N. and Gültekin, N.B. (1985) New Tests of the APT and Their Implications, The Journal of Finance, 40, 659-675.

Dumas, B., and Solnik, B. (1995) The world price of foreign exchange risk, Journal of Finance, 50, 445-479.

Dunteman, G.H. (1994) Principal Components Analysis, in Factor Analysis and Related Techniques, International Handbooks of Quantitative Applications in the Social Sciences, $5^{\text {th }}$ edn (Ed.) M.S. Lewis-Beck, Sage Publications, London, 157-245.

Fama, E.F. (1981) Stock Returns, Real Activity, Inflation and Money, American Economic Review, 71, 545-565.

Fama, E.F. and Schwert, G.W. (1977) Asset Returns and Inflation, Journal of Financial Economics, 5, 115-146.

Fama, E.F. (1991) Efficient capital markets: II, The Journal of Finance, 46, 1575-1617.

Ferson, W., and Harvey, C.R. (1994) Sources of risk and expected returns in global equity markets, Journal of Banking and Finance, 18, 775-803.

Fifield, S.G.M. and Power, D.M. (2006) The role of economic and fundamental factors in emerging market share returns: A comparison of Asian and Non-Asian countries, Journal of Accounting and Finance, 5, 1-18.

Fifield, S.G.M., Power, D.M. and Sinclair, C.D. (2002) Macroeconomic Factors and Share Returns: An Analysis Using Emerging Market Data, International Journal of Finance and Economics, 7, 51-62.

Firth, M. (1979) The Relationship Between Stock Market Returns and Rates of Inflation, The Journal of Finance, 3, 743-749.

Flannery, M.J. and Protopapadakis, A.A. (2002) Macroeconomic factors do influence aggregate stock returns, The Review of Financial Studies, 15, 751-782.

Flannery, M.J. and James, C.M. (1984) The effect of interest rate changes on the common stock returns of financial institutions, The Journal of Finance, 39, 1141-1153.

Gujarati, D. (2004) Basic Econometrics, 4th Edn, McGraw Hill, New York.

Gultekin, N.B. (1983) Stock Market Returns and Inflation: Evidence from Other Countries, The Journal of Finance, 38, 1, 115-146. 
Gunasekarage, A., Pisedtasalasai, A. and Power, D.M. (2004) Macroeconomic influences on the stock market: Evidence from an emerging market in South Asia, Journal of Emerging Market Finance, 3, 285-304.

Hanousek, J., Kocenda, E., and Kutan, A.M. (2009) The reaction of asset prices to macroeconomic announcements in new EU markets: Evidence from Intra-day data, Journal of Financial Stability, 5, 199-219.

Harvey, C.A. (1995) Predictable risk and returns in emerging markets, Review of Financial Studies, 8, 773-816.

Hondroyiannis, G., and Papapetrou, E. (2001) Macroeconomic influences on the stock market, Journal of Economics and Finance, 25, 33-49.

Humpe, A. and Macmillan, P. (2009) Can macroeconomic variables explain long-term stock market movements? A comparison of the US and Japan, Applied Financial Economics, 19, 111-119.

Jolliffe, I.T., (1972) Discarding Variables in a Principal Component Analysis In Artificial Data, Applied Statistics, 21, 160-173.

Kaiser, H.F. (1960) The Application of Electronic Computers to Factor Analysis, Educational and Psychological Measurement, 20, 141-151.

Khan, M.N. (2013) An analysis of market efficiency in the South Asian Emerging Stock Markets: Bangladesh, India, Pakistan and Sri Lanka, Unpublished PhD Thesis, School of Business, University of Dundee, UK.

Kim, K. (2003) Dollar exchange rate and stock price: evidence from multivariate cointegration and error correction model, Review of Financial Economics, 12, 301-313.

Lamba, A.S. (2005) An analysis of the short- and long-run relationships between South Asian and developed equity markets, International Journal of Business, 10, 383-402.

Lee, B. (1992) Causal relations among stock returns, interest rates, real activity and inflation, The Journal of Finance, 47, 1591-1603.

LeRoy, S.F. and Porter, R.D. (1981) The present value relation: Tests based on implied variance bounds, Econometrica, 49, 555-574.

Mahmood, M.W. and Dinniah, M.N. (2009) Stock Returns and Macroeconomic Variables: Evidence from Six Asian-Pacific Countries, International Research Journal of Finance and Economics, 30, 154-164.

Maysami, R.C., Howe, L.C. and Hamzah, M.A. (2004) Relationship between Macroeconomic Variables and Stock Market Indices: Cointegration Evidence from Stock Exchange of Singapore’s All-S Sector Indices, Journal Pengurusan, 24, 47-77. 
Mukherjee, T. K. and Naka, A. (1995) Dynamic relations between macroeconomic variables and the Japanese stock market: an application of a vector error correction model, The Journal of Financial Research, 18, 223-237.

Mun, K.C. (2012) The joint response of stock and foreign exchange markets to macroeconomic surprises: Using US and Japanese data, Journal of Banking and Finance, 36, 383-394.

Nasseh, A. and Strauss, J. (2000) Stock prices and domestic and international macroeconomic activity: a cointegration approach, The Quarterly Review of Economics and Finance, 40, 229-245.

Nelson, C.R. (1976) Inflation and Rates of Return on Common Stocks, The Journal of Finance, 31, 2, 471-183.

Poon, S. and S.J. Taylor, S.J. (1991) Macroeconomic Factors and the UK Stock Market, Journal of Business Finance and Accounting, 18, 619-636.

Rapach, D.E., Woharb, M.E. and Rangvid, J. (2005) Macro variables and international stock return predictability, International Journal of Forecasting, 21, 137- 166.

Ross, S.A. (1976) The Arbitrage Theory of Capital Asset Pricing, Journal of Economic Theory, 13, 341-360.

Shiller, R.J. (1981) Do stock prices move too much to be justified by subsequent changes in dividends? American Economic Review, 71, 421- 436.

Shiller, R.J. (1984) Theories of aggregate stock price movements, Journal of Portfolio Management, 10, 28-37.

Sing, T.F. and Low, S.H.Y. (2000) The Inflation-Hedging Characteristics of Real Estate and Financial Assets in Singapore, Journal of Real Estate Portfolio Management, 6, 373-385.

Sohail, N and Hussain, Z. (2009) Long-run and Short-run relationships between Macroeconomic variables and Stock Prices in Pakistan: The case of Lahore Stock Exchange, Pakistan Economic and Social Review, 47, 183-198.

Srinivasan, T. N. (2002) South Asia in the World Economy - Some Issues, in Trade, Finance and Investment in South Asia, T. N. Srinivasan (Ed.), Social Science Press, New Delhi, 1-27.

Verma, R., and Ozuna, T. (2005) Are emerging equity markets responsive to cross-country macroeconomic movements? Evidence from Latin America, International Financial Markets, Institutions and Money, 15, 73-87.

Walti, Sebastien (2005) The macroeconomic determinants of stock market synchronization, Working Paper, Trinity College Dublin, July.

Wongbangpo, P. and Sharma, S.C. (2002) Stock Market and Macroeconomic fundamentals dynamic interactions: ASEAN-5 countries. Journal of Asian Economics, 13, 27-51. 
World Bank (2010) Moving Up, Looking East, South Asia Economic Update, Washington DC.

World Bank (2012) Global Economic Prospects, South Asia.

World Bank (2013a) Trends and Determinants of Foreign Direct Investment in South Asia, June, Washington DC.

World Bank (2013b) Regaining Momentum. South Asia Economic Focus, Spring, Washington DC.

Zhou, T.T., Gunasekarage, A. and Power, D.M. (2005) Do Real Estate Assets Hedge Inflation Better Than Financial Assets? Some New Zealand Evidence, Briefings in Real Estate Finance, 5, 39-46. 


\section{Appendix}

Table 1. Summary statistics for economic variables 1998-2012

\begin{tabular}{|c|c|c|c|c|c|c|c|c|}
\hline & & $\mathbf{R}$ & CPI & FX & IPI & MS & TB & TBR \\
\hline \multirow[t]{2}{*}{ Bangladesh } & Mean & 0.010 & 0.005 & 0.003 & 0.005 & 0.011 & 0.016 & 0.0021 \\
\hline & SD & 0.080 & 0.009 & 0.012 & 0.096 & 0.034 & 0.012 & 0.1172 \\
\hline \multirow[t]{2}{*}{ India } & Mean & 0.011 & 0.005 & 0.002 & 0.006 & 0.012 & 0.055 & 0.0009 \\
\hline & SD & 0.079 & 0.006 & 0.017 & 0.078 & 0.052 & 0.190 & 0.0846 \\
\hline \multirow[t]{2}{*}{ Pakistan } & Mean & 0.012 & 0.001 & 0.004 & 0.003 & 0.012 & 0.003 & 0.0024 \\
\hline & SD & 0.110 & 0.062 & 0.014 & 0.101 & 0.031 & 0.170 & 0.0858 \\
\hline \multirow[t]{2}{*}{ Sri Lanka } & Mean & 0.013 & 0.005 & 0.004 & 0.004 & 0.009 & 0.087 & 0.0004 \\
\hline & SD & 0.085 & 0.034 & 0.016 & 0.072 & 0.025 & 0.160 & 0.0537 \\
\hline \multirow[t]{3}{*}{ Regional } & & RMV & RCPI & RGDP & RINT & RTB & RMS & \\
\hline & Mean & -0.0001 & -0.0003 & -0.0003 & 0.012 & -0.003 & 0.012 & \\
\hline & SD & 0.454 & 0.064 & 0.058 & 0.083 & 0.020 & 0.052 & \\
\hline \multirow[t]{3}{*}{ World } & \multirow[b]{2}{*}{ Mean } & WRET & WCPI & WGDP & OIL & USTBR & & \\
\hline & & 0.002 & 0.003 & 0.005 & 0.011 & -0.025 & & \\
\hline & $\mathrm{SD}$ & 0.053 & 0.002 & 0.022 & 0.100 & 0.433 & & \\
\hline
\end{tabular}

The table shows the mean and standard deviation of the stock market return (R) and the growth rates of economic variables. The local economic variables include the consumer price index (CPI), the foreign exchange rate (FX), the industrial production index (IPI), money supply (MS) and trade balance (TB), and the Treasurybill rate (TBR). The regional economic variables include regional market value as a percentage of regional GDP (RMV), regional CPI (RCPI), regional GDP (RGDP), inter-regional trade as a percentage of regional GDP (RINT), regional trade balance as a percentage of regional GDP (RTB), and regional money supply as a percentage of GDP (RMS). The world variables include the world market return (WRET), world CPI (WCPI), world gross domestic product (WGDP), oil prices (OIL) and the US three month Treasury-bill rate as a proxy for the world risk-free rate (USTBR). 
Table 2. Eigenvalues and proportions of variance explained by the principal components

\begin{tabular}{|c|c|c|c|c|c|c|c|}
\hline \multirow[t]{2}{*}{ Country } & & \multicolumn{6}{|c|}{ Principal Components } \\
\hline & & 1 & 2 & 3 & 4 & 5 & 6 \\
\hline \multirow[t]{3}{*}{ Bangladesh } & Eigenvalue & 1.308 & 1.153 & 1.001 & 0.952 & 0.850 & 0.734 \\
\hline & Proportion & 0.218 & 0.192 & 0.167 & 0.159 & 0.142 & 0.122 \\
\hline & Cum-Proportion & 0.218 & 0.410 & 0.577 & 0.736 & 0.878 & 1.000 \\
\hline \multirow[t]{3}{*}{ India } & Eigenvalue & 1.720 & 1.171 & 1.019 & 0.944 & 0.856 & 0.289 \\
\hline & Proportion & 0.287 & 0.195 & 0.169 & 0.157 & 0.142 & 0.048 \\
\hline & Cum-Proportion & 0.287 & 0.482 & 0.652 & 0.809 & 0.952 & 1.000 \\
\hline \multirow[t]{3}{*}{ Pakistan } & Eigenvalue & 1.988 & 1.167 & 1.134 & 0.936 & 0.720 & 0.053 \\
\hline & Proportion & 0.331 & 0.194 & 0.189 & 0.156 & 0.120 & 0.009 \\
\hline & Cum-Proportion & 0.331 & 0.526 & 0.715 & 0.871 & 0.991 & 1.000 \\
\hline \multirow[t]{3}{*}{ Sri Lanka } & Eigenvalue & 1.346 & 1.081 & 1.033 & 0.939 & 0.845 & 0.753 \\
\hline & Proportion & 0.224 & 0.180 & 0.172 & 0.157 & 0.141 & 0.126 \\
\hline & Cum-Proportion & 0.224 & 0.405 & 0.577 & 0.733 & 0.874 & 1.000 \\
\hline \multirow[t]{3}{*}{ Regional } & Eigenvalue & 3.320 & 1.246 & 0.774 & 0.552 & 0.085 & 0.022 \\
\hline & Proportion & 0.553 & 0.208 & 0.129 & 0.092 & 0.014 & 0.003 \\
\hline & Cum-Proportion & 0.553 & 0.761 & 0.890 & 0.982 & 0.996 & 1.000 \\
\hline \multirow[t]{3}{*}{ World } & Eigenvalue & 1.832 & 1.249 & 0.925 & 0.640 & 0.352 & 0.000 \\
\hline & Proportion & 0.366 & 0.250 & 0.185 & 0.128 & 0.070 & 0.000 \\
\hline & Cum- Proportion & 0.366 & 0.616 & 0.801 & 0.929 & 1.000 & 0.000 \\
\hline
\end{tabular}

The emboldened values indicate those PCs with eigenvalues greater than one, as well as those PCs which account for a large portion of the variation in the data. The cumulative proportion (Cum-Proportion) explained by the first three local PCs is greater than 57 percent. The first two regional and global PCs explained a cumulative proportion of 76.1 and 61.6 percent, respectively. 
Table 3. Dominant principal components

\begin{tabular}{|l|l|l|l|}
\hline Countries & \multicolumn{3}{|c|}{ Local and Global Economic Factors } \\
\hline & LPC1 & LPC2 & LPC3 \\
\hline Bangladesh & $\begin{array}{l}\text { TBR, MS } \\
\text { (real interest rate) }\end{array}$ & $\begin{array}{l}\text { IPI, FX, TB } \\
\text { (economic activity) }\end{array}$ & $\begin{array}{l}\text { FX, TB, CPI } \\
\text { (real exchange rate) }\end{array}$ \\
\hline India & $\begin{array}{l}\text { IPI, MS } \\
\text { (economic activity) }\end{array}$ & $\begin{array}{l}\text { FX, TB } \\
\text { (real exchange rate) }\end{array}$ & $\begin{array}{l}\text { CPI, TBR } \\
\text { (real interest rate) }\end{array}$ \\
\hline Pakistan & $\begin{array}{l}\text { TB, MS } \\
\text { (trade deficits) }\end{array}$ & $\begin{array}{l}\text { IPI, CPI } \\
\text { (economic activity) }\end{array}$ & FX, CPI, TBR \\
(real exchange rate)
\end{tabular}


Table 4. Regression analysis of monthly stock returns for the four South Asian emerging markets

\begin{tabular}{|c|c|c|c|c|c|c|c|c|}
\hline \multirow[t]{2}{*}{ Variables } & \multicolumn{4}{|c|}{ Equation (1) } & \multicolumn{4}{|c|}{ Equation (2) } \\
\hline & BDSE & INSE & PKSE & SLSE & BDSE & INSE & PKSE & SLSE \\
\hline Constant & $\begin{array}{c}0.008 \\
(0.006)\end{array}$ & $\begin{array}{c}0.010 \\
(0.006)\end{array}$ & $\begin{array}{c}0.013 \\
(0.008)\end{array}$ & $\begin{array}{l}\text { 0.012* } \\
(0.006)\end{array}$ & $\begin{array}{l}\mathbf{- 0 . 1 4 2 * *} \\
(0.056)\end{array}$ & $\begin{array}{c}0.051 \\
(0.055)\end{array}$ & $\begin{array}{c}-0.075 \\
(0.154)\end{array}$ & $\begin{array}{c}-0.064 \\
(0.050)\end{array}$ \\
\hline $\mathbf{R}_{\mathbf{t}-\mathbf{1}}$ & $\begin{array}{l}-0.006 \\
(0.079) \\
\end{array}$ & $\begin{array}{c}0.089 \\
(0.077) \\
\end{array}$ & $\begin{array}{c}0.008 \\
(0.068)\end{array}$ & $\begin{array}{c}0.090 \\
(0.056)\end{array}$ & $\begin{array}{c}-0.076 \\
(0.070) \\
\end{array}$ & $\begin{array}{c}-0.003 \\
(0.083) \\
\end{array}$ & $\begin{array}{c}-0.007 \\
(0.066) \\
\end{array}$ & $\begin{array}{c}0.028 \\
(0.055) \\
\end{array}$ \\
\hline LPC1 & $\begin{array}{c}\text { 0.243** } \\
(0.080)\end{array}$ & $\begin{array}{c}-0.006 \\
(0.005)\end{array}$ & $\begin{array}{l}\mathbf{- 0 . 1 2 3} * * \\
(0.035) \\
\end{array}$ & $\begin{array}{l}\mathbf{0 . 3 6 7} * * \\
(0.144)\end{array}$ & $\begin{array}{l}\text { 0.195** } \\
(0.075) \\
\end{array}$ & $\begin{array}{c}-0.006 \\
(0.005)\end{array}$ & $\begin{array}{l}\mathbf{- 0 . 1 3 6 * *} \\
(0.046) \\
\end{array}$ & $\begin{array}{c}\mathbf{0 . 3 2 0} \text { *** } \\
(0.147)\end{array}$ \\
\hline LPC2 & $\begin{array}{c}0.016 \\
(0.062) \\
\end{array}$ & $\begin{array}{c}0.002 \\
(0.014) \\
\end{array}$ & $\begin{array}{c}0.078 \\
(0.074) \\
\end{array}$ & $\begin{array}{c}\mathbf{- 0 . 3 3 4 * *} \\
(0.142) \\
\end{array}$ & $\begin{array}{c}-0.012 \\
(0.073) \\
\end{array}$ & $\begin{array}{c}0.014 \\
(0.016) \\
\end{array}$ & $\begin{array}{c}0.088 \\
(0.074) \\
\end{array}$ & $\begin{array}{c}\mathbf{- 0 . 2 5 4 *} \\
(0.151) \\
\end{array}$ \\
\hline LPC3 & $\begin{array}{c}-0.125 \\
(0.076) \\
\end{array}$ & $\begin{array}{c}0.011 \\
(0.030) \\
\end{array}$ & $\begin{array}{l}\mathbf{- 0 . 4 4 1 * *} \\
(0.125) \\
\end{array}$ & $\begin{array}{c}-0.135 \\
(0.006) \\
\end{array}$ & $\begin{array}{c}-0.089 \\
(0.081) \\
\end{array}$ & $\begin{array}{c}0.006 \\
(0.030) \\
\end{array}$ & $\begin{array}{l}\mathbf{- 0 . 4 5 3 * *} \\
(0.140) \\
\end{array}$ & $\begin{array}{c}-0.111 \\
(0.085) \\
\end{array}$ \\
\hline RPC1 & N/A & N/A & N/A & N/A & $\begin{array}{l}\mathbf{0 . 0 2 0} * \\
(0.012)\end{array}$ & $\begin{array}{c}-0.011 \\
(0.014)\end{array}$ & $\begin{array}{c}0.014 \\
(0.033)\end{array}$ & $\begin{array}{c}\mathbf{0 . 0 2 1}^{* * *} \\
(0.010)\end{array}$ \\
\hline RPC2 & N/A & N/A & N/A & N/A & $\begin{array}{c}\text { 0.012** } \\
(0.005) \\
\end{array}$ & $\begin{array}{c}0.005 \\
(0.008) \\
\end{array}$ & $\begin{array}{c}0.004 \\
(0.009) \\
\end{array}$ & $\begin{array}{c}-0.008 \\
(0.006) \\
\end{array}$ \\
\hline GPC1 & N/A & N/A & N/A & N/A & $\begin{array}{c}0.005 \\
(0.003)\end{array}$ & $\begin{array}{c}-0.004 \\
(0.004)\end{array}$ & $\begin{array}{c}0.001 \\
(0.004)\end{array}$ & $\begin{array}{c}-0.001 \\
(0.003)\end{array}$ \\
\hline GPC2 & N/A & N/A & N/A & N/A & $\begin{array}{c}-0.006 \\
(0.004)\end{array}$ & $\begin{array}{c}0.007 \\
(0.006)\end{array}$ & $\begin{array}{c}-0.001 \\
(0.006)\end{array}$ & $\begin{array}{c}0.002 \\
(0.005)\end{array}$ \\
\hline $\mathbf{R}^{2 \%}$ & 6.3 & 0.9 & 6.7 & 7.2 & 14.7 & 5.0 & 8.8 & 12.8 \\
\hline Adj. $R^{2} \%$ & 4.2 & 0.0 & 4.6 & 5.0 & 10.7 & 0.5 & 4.5 & 8.7 \\
\hline
\end{tabular}

The table reports results from regressing the lagged local, regional and global PCs on the monthly returns of the four South Asian markets over the 15-year period 1998-2012. In particular, the table reports the coefficient values for the local, regional and global PCs, the $\mathrm{R}^{2}$ and the adjusted $\mathrm{R}^{2}$. Values in parentheses are standard errors of the coefficients. $* *$ and $*$ indicate significance of the coefficients at the 5 and 10 percent level, respectively. 
Table 5. Estimates of the VAR models for the four South Asian emerging markets

\begin{tabular}{|c|c|c|c|c|c|c|c|c|c|c|c|c|c|c|c|c|}
\hline & \multicolumn{4}{|c|}{ Bangladesh } & \multicolumn{4}{|c|}{ India } & \multicolumn{4}{|c|}{ Pakistan } & \multicolumn{4}{|c|}{ Sri Lanka } \\
\hline & $\mathrm{R}_{\mathrm{t}}$ & $\mathrm{LPC1}_{\mathrm{t}}$ & $\mathrm{LPC}_{\mathrm{t}}$ & $\mathrm{LPC3}_{\mathrm{t}}$ & $\mathrm{R}_{\mathrm{t}}$ & $\mathrm{LPC}_{\mathrm{t}}$ & $\mathrm{LPC}_{\mathrm{t}}$ & $\mathrm{LPC3}_{\mathrm{t}}$ & $\mathrm{R}_{\mathrm{t}}$ & $\mathrm{LPC1}_{\mathrm{t}}$ & $\mathrm{LPC}_{\mathrm{t}}$ & $\mathrm{LPC}_{\mathrm{t}}$ & $\mathrm{R}_{\mathrm{t}}$ & $\mathrm{LPC1}_{\mathrm{t}}$ & $\mathrm{LPC} 2_{\mathrm{t}}$ & $\mathrm{LPC3}_{\mathrm{t}}$ \\
\hline $\mathrm{C}$ & $-0.133^{* *}$ & $0.433^{* *}$ & $-0.655^{* *}$ & $0.878 * *$ & 0.057 & $6.377^{* *}$ & 0.168 & -0.775 & -0.072 & $-0.999 * *$ & $-0.264 *$ & 0.080 & -0.054 & $0.500 * *$ & $0.563 * *$ & 0.050 \\
\hline & $(0.056)$ & $(0.132)$ & $(0.134)$ & $(0.179)$ & $(0.054)$ & (3.136) & $(0.444)$ & $(0.626)$ & $(0.134)$ & 13) & 157) & $(0.101)$ & $(0.057)$ & 146) & $(0.1$ & $(0.043)$ \\
\hline $\mathrm{R}_{\mathrm{BDt}-1}$ & $\begin{array}{l}-0.067 \\
(0.076)\end{array}$ & $\begin{array}{c}0.009 \\
(0.181)\end{array}$ & $\begin{array}{l}-0.093 \\
(0.184)\end{array}$ & $\begin{array}{c}0.071 \\
(0.245)\end{array}$ & $\begin{array}{c}0.050 \\
(0.077)\end{array}$ & $\begin{array}{l}-1.128 \\
(4.443)\end{array}$ & $\begin{array}{l}-0.397 \\
(0.629)\end{array}$ & $\begin{array}{c}0.080 \\
(0.886)\end{array}$ & $\begin{array}{c}0.068 \\
(0.107)\end{array}$ & $\begin{array}{c}0.366 \\
(0.251)\end{array}$ & $\begin{array}{c}0.095 \\
(0.126)\end{array}$ & $\begin{array}{l}-0.066 \\
(0.081)\end{array}$ & $\begin{array}{c}0.124 \\
(0.081)\end{array}$ & $\begin{array}{c}0.270 \\
(0.208)\end{array}$ & $\begin{array}{c}0.237 \\
(0.204)\end{array}$ & $\begin{array}{l}\text { 0.110* } \\
(0.062)\end{array}$ \\
\hline $\mathrm{R}_{\mathrm{IN} \mathrm{t}-1}$ & $\begin{array}{c}0.055 \\
(0.091)\end{array}$ & $\begin{array}{c}0.255 \\
(0.217)\end{array}$ & $\begin{array}{r}-\mathbf{0 . 5 3 4 * *} \\
(0.220)\end{array}$ & $\begin{array}{c}0.368 \\
(0.294)\end{array}$ & $\begin{array}{l}-0.062 \\
(0.090)\end{array}$ & $\begin{array}{c}0.129 \\
(5.244)\end{array}$ & $\begin{array}{l}-0.408 \\
(0.742)\end{array}$ & $\begin{array}{c}0.051 \\
(1.046)\end{array}$ & $\begin{array}{l}-0.032 \\
(0.127)\end{array}$ & $\begin{array}{c}0.373 \\
(0.298)\end{array}$ & $\begin{array}{l}-0.090 \\
(0.149)\end{array}$ & $\begin{array}{l}-0.132 \\
(0.096)\end{array}$ & $\begin{array}{l}-0.006 \\
(0.095)\end{array}$ & $\begin{array}{c}0.003 \\
(0.244)\end{array}$ & $\begin{array}{c}0.037 \\
(0.239)\end{array}$ & $\begin{array}{c}0.021 \\
(0.072)\end{array}$ \\
\hline $\mathrm{R}_{\mathrm{PK} \mathrm{t}-1}$ & $\begin{array}{c}0.065 \\
(0.057)\end{array}$ & $\begin{array}{l}-0.111 \\
(0.136)\end{array}$ & $\begin{array}{c}0.105 \\
(0.138)\end{array}$ & $\begin{array}{l}-0.167 \\
(0.184)\end{array}$ & $\begin{array}{c}\mathbf{0 . 1 3 3} * * \\
(0.056)\end{array}$ & $\begin{array}{c}1.023 \\
(3.223)\end{array}$ & $\begin{array}{c}0.100 \\
(0.456)\end{array}$ & $\begin{array}{l}-0.232 \\
(0.643)\end{array}$ & $\begin{array}{c}0.012 \\
(0.078)\end{array}$ & $\begin{array}{c}0.172 \\
(0.182)\end{array}$ & $\begin{array}{c}0.018 \\
(0.091)\end{array}$ & $\begin{array}{l}-0.032 \\
(0.059)\end{array}$ & $\begin{array}{c}0.008 \\
(0.058)\end{array}$ & $\begin{array}{c}0.046 \\
(0.149)\end{array}$ & $\begin{array}{c}0.011 \\
(0.146)\end{array}$ & $\begin{array}{c}0.028 \\
(0.044)\end{array}$ \\
\hline $\mathrm{R}_{\mathrm{SL} t-1}$ & $\begin{array}{l}-0.060 \\
(0.072)\end{array}$ & $\begin{array}{c}0.165 \\
(0.171)\end{array}$ & $\begin{array}{c}0.052 \\
(0.173)\end{array}$ & $\begin{array}{c}0.056 \\
(0.231)\end{array}$ & $\begin{array}{c}0.077 \\
(0.073)\end{array}$ & $\begin{array}{l}-3.955 \\
(4.238)\end{array}$ & $\begin{array}{l}-0.816 \\
(0.600)\end{array}$ & $\begin{array}{c}0.987 \\
(0.845)\end{array}$ & $\begin{array}{l}-0.063 \\
(0.102)\end{array}$ & $\begin{array}{l}-0.171 \\
(0.239)\end{array}$ & $\begin{array}{l}-0.064 \\
(0.120)\end{array}$ & $\begin{array}{c}0.005 \\
(0.077)\end{array}$ & $\begin{array}{c}0.030 \\
(0.077)\end{array}$ & $\begin{array}{c}0.318 \\
(0.197)\end{array}$ & $\begin{array}{c}0.251 \\
(0.193)\end{array}$ & $\begin{array}{r}\mathbf{0 . 1 3 0} * * \\
(0.058)\end{array}$ \\
\hline $\mathrm{LPC}_{\mathrm{t}-1}$ & $\begin{array}{c}\mathbf{0 . 2 1 4} * * \\
(0.087)\end{array}$ & $\begin{array}{c}0.095 \\
(0.208)\end{array}$ & $\begin{array}{l}-0.287 \\
(0.210)\end{array}$ & $\begin{array}{c}0.204 \\
(0.281)\end{array}$ & $\begin{array}{l}-0.005 \\
(0.016)\end{array}$ & $\begin{array}{c}0.411 \\
(0.916)\end{array}$ & $\begin{array}{c}0.136 \\
(0.130)\end{array}$ & $\begin{array}{l}-0.125 \\
(0.183)\end{array}$ & $\begin{array}{c}\mathbf{- 0 . 1 3 9} * * \\
(0.044)\end{array}$ & $\begin{array}{c}\mathbf{0 . 9 0 6}^{* *} \\
(0.104)\end{array}$ & $\begin{array}{c}\mathbf{0 . 1 2 6}^{* *} \\
(0.052)\end{array}$ & $\begin{array}{c}\mathbf{- 0 . 1 5 7 * *} \\
(0.034)\end{array}$ & $\begin{array}{c}\mathbf{0 . 3 2 7 * *} \\
(0.145)\end{array}$ & $\begin{array}{l}-0.187 \\
(0.372)\end{array}$ & $\begin{array}{l}-0.396 \\
(0.365)\end{array}$ & $\begin{array}{l}-0.115 \\
(0.110)\end{array}$ \\
\hline LPC2 ${ }_{\mathrm{t}-1}$ & $\begin{array}{l}-0.017 \\
(0.070)\end{array}$ & $\begin{array}{r}-\mathbf{0 . 4 3 2 * *} \\
(0.166)\end{array}$ & $\begin{array}{c}\mathbf{0 . 2 5 3} \\
(0.168)\end{array}$ & $\begin{array}{r}-\mathbf{0 . 6 2 2 * *} \\
(0.224)\end{array}$ & $\begin{array}{c}0.018 \\
(0.021)\end{array}$ & $\begin{array}{c}\text { 3.025** } \\
(1.190)\end{array}$ & $\begin{array}{c}\text { 1.137** } \\
(0.168)\end{array}$ & $\begin{array}{r}-\mathbf{0 . 7 3 1} * * \\
(0.237)\end{array}$ & $\begin{array}{c}0.093 \\
(0.084)\end{array}$ & $\begin{array}{r}-\mathbf{0 . 6 0 7 * *} \\
(0.197)\end{array}$ & $\begin{array}{l}-0.076 \\
(0.099)\end{array}$ & $\begin{array}{c}0.102 \\
(0.064)\end{array}$ & $\begin{array}{r}\mathbf{- 0 . 2 6 3 *} \\
(0.150)\end{array}$ & $\begin{array}{c}\mathbf{0 . 8 6 0} * * \\
(0.384)\end{array}$ & $\begin{array}{c}\text { 1.051** } \\
(0.376)\end{array}$ & $\begin{array}{c}0.113 \\
(0.114)\end{array}$ \\
\hline LPC3 ${ }_{t-1}$ & $\begin{array}{l}-0.108 \\
(0.083)\end{array}$ & $\begin{array}{c}0.012 \\
(0.196)\end{array}$ & $\begin{array}{l}-0.092 \\
(0.199)\end{array}$ & $\begin{array}{l}-0.005 \\
(0.265)\end{array}$ & $\begin{array}{c}0.006 \\
(0.033)\end{array}$ & $\begin{array}{c}0.090 \\
(1.955)\end{array}$ & $\begin{array}{l}-0.063 \\
(0.277)\end{array}$ & $\begin{array}{c}0.201 \\
(0.390)\end{array}$ & $\begin{array}{r}-\mathbf{0 . 4 6 0} * * \\
(0.132)\end{array}$ & $\begin{array}{l}-0.167 \\
(0.309)\end{array}$ & $\begin{array}{l}-0.054 \\
(0.155)\end{array}$ & $\begin{array}{c}\mathbf{0 . 3 5 0 * *} \\
(0.100)\end{array}$ & $\begin{array}{l}-0.093 \\
(0.092)\end{array}$ & $\begin{array}{c}\text { 0.512** } \\
(0.236)\end{array}$ & $\begin{array}{c}\text { 0.536** } \\
(0.232)\end{array}$ & $\begin{array}{c}\mathbf{- 0 . 4 0 1} * * \\
(0.070)\end{array}$ \\
\hline $\mathrm{RPC}_{\mathrm{t}-1}$ & $\begin{array}{c}0.018 \\
(0.012)\end{array}$ & $\begin{array}{c}-\mathbf{0 . 1 1 1} * * \\
(0.029)\end{array}$ & $\begin{array}{c}\text { 0.152** } \\
(0.030)\end{array}$ & $\begin{array}{c}\mathbf{- 0 . 2 1 3} * * \\
(0.040)\end{array}$ & $\begin{array}{l}-0.013 \\
(0.012)\end{array}$ & $\begin{array}{c}\mathbf{- 1 . 2 1 3 *} \\
(0.720)\end{array}$ & $\begin{array}{c}0.016 \\
(0.102)\end{array}$ & $\begin{array}{c}0.113 \\
(0.144)\end{array}$ & $\begin{array}{c}0.015 \\
(0.029)\end{array}$ & $\begin{array}{c}\text { 0.226** } \\
(0.069)\end{array}$ & $\begin{array}{c}0.050 \\
(0.034)\end{array}$ & $\begin{array}{l}-0.027 \\
(0.022)\end{array}$ & $\begin{array}{c}0.020 \\
(0.013)\end{array}$ & $\begin{array}{c}-\mathbf{0 . 1 2 6} * * \\
(0.034)\end{array}$ & $\begin{array}{c}-\mathbf{0 . 1 4 5} * * \\
(0.033)\end{array}$ & $\begin{array}{l}-0.012 \\
(0.010)\end{array}$ \\
\hline RPC2 $\mathrm{t}-1$ & $\begin{array}{c}\mathbf{0 . 0 1 2} * * \\
(0.006)\end{array}$ & $\begin{array}{r}\mathbf{0 . 0 3 8} * * \\
(0.015)\end{array}$ & $\begin{array}{c}-\mathbf{0 . 0 2 8} * \\
(0.015)\end{array}$ & $\begin{array}{c}\mathbf{0 . 0 5 8} * * \\
(0.020)\end{array}$ & $\begin{array}{c}0.005 \\
(0.007)\end{array}$ & $\begin{array}{c}0.056 \\
(0.382)\end{array}$ & $\begin{array}{l}-0.050 \\
(0.054)\end{array}$ & $\begin{array}{c}0.031 \\
(0.076)\end{array}$ & $\begin{array}{c}0.003 \\
(0.009)\end{array}$ & $\begin{array}{c}-\mathbf{0 . 0 3 9 *} \\
(0.022)\end{array}$ & $\begin{array}{c}0.003 \\
(0.011)\end{array}$ & $\begin{array}{l}\text { 0.015* } \\
(0.007)\end{array}$ & $\begin{array}{l}-0.010 \\
(0.007)\end{array}$ & $\begin{array}{l}\text { 0.036* } \\
(0.019)\end{array}$ & $\begin{array}{c}\text { 0.045** } \\
(0.018)\end{array}$ & $\begin{array}{c}0.003 \\
(0.006)\end{array}$ \\
\hline GPC1 $1_{\mathrm{t}-1}$ & $\begin{array}{c}0.004 \\
(0.003)\end{array}$ & $\begin{array}{l}-0.010 \\
(0.007)\end{array}$ & $\begin{array}{c}0.005 \\
(0.007)\end{array}$ & $\begin{array}{l}-0.015 \\
(0.010)\end{array}$ & $\begin{array}{l}-0.005 \\
(0.003)\end{array}$ & $\begin{array}{l}-0.101 \\
(0.176)\end{array}$ & $\begin{array}{c}0.011 \\
(0.025)\end{array}$ & $\begin{array}{c}0.012 \\
(0.035)\end{array}$ & $\begin{array}{c}0.001 \\
(0.004)\end{array}$ & $\begin{array}{c}0.004 \\
(0.010)\end{array}$ & $\begin{array}{l}-0.005 \\
(0.005)\end{array}$ & $\begin{array}{r}-0.0003 \\
(0.003)\end{array}$ & $\begin{array}{r}-0.0003 \\
(0.003)\end{array}$ & $\begin{array}{l}-0.012 \\
(0.008)\end{array}$ & $\begin{array}{l}-0.011 \\
(0.008)\end{array}$ & $\begin{array}{l}-0.004 \\
(0.002)\end{array}$ \\
\hline GPC2 t-1 & $\begin{array}{l}-0.006 \\
(0.004) \\
\end{array}$ & $\begin{array}{c}0.015 \\
(0.011) \\
\end{array}$ & $\begin{array}{l}-0.007 \\
(0.011) \\
\end{array}$ & $\begin{array}{c}0.022 \\
(0.014)\end{array}$ & $\begin{array}{c}\mathbf{0 . 0 0 8} * \\
(0.005) \\
\end{array}$ & $\begin{array}{c}0.154 \\
(0.265) \\
\end{array}$ & $\begin{array}{l}-0.014 \\
(0.038)\end{array}$ & $\begin{array}{l}-0.019 \\
(0.053) \\
\end{array}$ & $\begin{array}{r}-0.0003 \\
(0.006) \\
\end{array}$ & $\begin{array}{l}-0.007 \\
(0.015) \\
\end{array}$ & $\begin{array}{c}0.007 \\
(0.007) \\
\end{array}$ & $\begin{array}{c}0.001 \\
(0.005) \\
\end{array}$ & $\begin{array}{c}0.002 \\
(0.005) \\
\end{array}$ & $\begin{array}{c}0.017 \\
(0.012) \\
\end{array}$ & $\begin{array}{c}0.016 \\
(0.012) \\
\end{array}$ & $\begin{array}{c}0.005 \\
(0.004) \\
\end{array}$ \\
\hline $\mathrm{R}^{-}$ & 15.9 & 76.6 & 82.5 & 82.1 & 9.2 & 7.0 & 57.4 & 18.5 & 9.3 & 96.7 & 74.9 & 94.4 & 14.0 & 81.9 & 83.2 & 24.1 \\
\hline Adj. $\mathrm{R}^{2}$ & 10.3 & 75.0 & 81.3 & 81.0 & 3.2 & 0.8 & 54.6 & 13.1 & 3.2 & 96.4 & 73.2 & 94.0 & 8.3 & 80.7 & 82.1 & 19.0 \\
\hline
\end{tabular}

The table reports results from regressing the VAR(1) model for the four South Asian markets over the 15-year period 1998-2012. In particular, the table reports the

coefficient values for the lagged returns, the lagged local, regional and global PCs, the $\mathrm{R}^{2}$ and the adjusted $\mathrm{R}^{2}$. Values in parentheses are standard errors of the coefficients.

** and * indicate significance of the coefficients at the 5 and 10 percent level, respectively. 